\title{
Adhesion to neuropathic pain treatment
}

\author{
Adesão ao tratamento da dor neuropática \\ Mirlane Guimarães de Melo Cardoso', José Guilherme Weinstock², Jamir João Sardá Júnior ${ }^{3}$
}

DOI 10.5935/1806-0013.20160060

\section{ABSTRACT}

BACKGROUND AND OBJECTIVES: In recent decades the concept of adherence is evolving from one-dimensional approach, limited to following a medication regimen, to the understanding of factors involved in the success or failure of a treatment. In particular, neuropathic pain is characterized by treatment failure associated with high costs. In a recent literature review, non compliance rate with prescriptions for chronic pain ranged from 8 to $62 \%$, and especially for neuropathic pain, the rate was $18 \%$. The objective of this study was to investigate in Pubmed/Medline and Scielo databases publications regarding adherence to neuropathic pain treatment in the last ten years.

CONTENTS: Descriptors used were: adherence, pain, neuropathic pain and compliance pain. It can be seen that in most studies ( 46 articles found in Pubmed and 49 in Scielo) adherence was examined with emphasis on adverse effects or efficacy associated with the use of drugs, or comparing the effects of two medications. Furthermore, 17 articles at Pubmed and 13 articles at Scielo focused on compliance of professionals with guidelines proposed by guideline entities.

CONCLUSION: There are a few publications on adherence to neuropathic pain treatment. In general, most researches in this area deal with the effectiveness of medications. Few studies investigate the participation of psychosocial aspects in the adherence process. Given these findings we concluded that it is necessary to produce more knowledge related to this topic, expanding the understanding of this phenomenon considering biopsychosocial aspects.

Keywords: Adherence, Compliance, Neuropathic pain, Pain.

\section{RESUMO}

JUSTIFICATIVA E OBJETIVOS: Nas últimas décadas o conceito de adesão vem evoluindo do enfoque unidimensional, limitado a seguimento de um regime farmacológico para a compreensão dos fatores envolvidos no sucesso ou fracasso de um tratamento. Particularmente, a dor neuropática é caracterizada pela falha no tratamento associado a elevados custos. Em recente revisão da literatura, a taxa de não adesão às prescrições para dor crônica variou de 8 a $62 \%$, particularmente na dor neuropática a taxa foi de $18 \%$. O objetivo deste estudo foi investigar nas bases de dados Pubmed/Medline e Scielo as publicaçōes referentes à adesão ao tratamento da dor neuropática nos últimos 10 anos.

CONTEÚDO: Os descritores utilizados foram: "adherence", "pain", "neuropathic pain" e "compliance pain". Pode se constatar que a maioria das pesquisas (46 artigos encontrados no Pubmed e 49 no Scielo) examinou a adesão com ênfase no efeito adverso ou eficácia associada ao uso de fármacos, ou comparando os efeitos de dois fármacos. Além disto, foram encontrados 17 artigos no Pubmed e 13 artigos do Scielo, que apresentaram como foco de pesquisa á adesão dos profissionais as diretrizes propostas por entidades "guidelines".

CONCLUSÃO: Existe um número reduzido de publicaçōes sobre adesão ao tratamento da dor neuropática. Em geral a maior parte das pesquisas nesta área

1. Universidade Federal do Amazonas, Departamento de Ciências Fisiológicas, Fundação Centro de Controle de Oncologia do Estado do Amazonas, Serviço de Terapia da Dor e Cuidados Paliativos, Manaus, AM, Brasil.

2. Hospital do Servidor Público do Estado de Sáo Paulo, Grupo Especializado em Dor da Neurocirurgia, Sáo Paulo, SP, Brasil.

3. Universidade do Vale do Itajaí, Curso de Psicologia, Clínica Espaço da Articulação Temporomandibular, Soma Clínica da Dor, Florianópolis, SC, Brasil.

Conflict of interests: none - Sponsoring sources: none.

Correspondence to:

Mirlane Guimaráes de Melo Cardoso

Av Mário Ypiranga 1601/602 - Adrianópolis

Av Mário Ypiranga 1601/602 - Adra

69057-002 Manaus, AM, Brasil.

(c) Sociedade Brasileira para o Estudo da Dor aborda a eficácia dos fármacos. Poucos artigos investigam a participação dos aspectos psicossociais no processo de adesão. Diante destes resultados concluiu-se que é necessário produzir mais conhecimento sobre este tema, ampliando a compreensão deste fenômeno considerando os aspectos biopsicossociais.

Descritores: Adesão, Conformidade, Dor, Dor neuropática.

\section{INTRODUCTION}

Neuropathic pain (NP) may be induced by several diseases and associated clinical conditions which impair diagnosis, and its treatment represents a major challenge. Antidepressants and anticonvulsants are the basis for the treatment and, as in other painful conditions, one should consider the potential for unbearable adverse effects even in therapeutic doses, which interfere with quality of life (QL) and impair adherence to treatment. In a recent literature review, the rate of non-adherence to chronic pain prescriptions has varied from $8 \%$ to $62 \%^{1}$, and specifically for neuropathic pain the rate was $18 \%^{2}$. Underuse was more frequent than overuse and was associated to active coping strategies and self-medication in most studies.

Age, pain intensity, dose, polypharmacy, physician-patient relationship quality, class of prescribed drugs and perception of the need for continuous analgesic drugs, were factors associated to non-adherence ${ }^{2}$. Adherence to treatment, then, is critically important for the perspective of a quality life.

Adherence may be defined as the extension to which the behavior of a person with regard to drug use follows a diet or changing lifestyle, is in compliance with health professionals recommendations ${ }^{3}$. Although the term compliance is sometimes used as synonym to adherence, its meaning refers to agreement or conformity with a treatment. Starting from this etimologic difference, it is implicit that the concept of adherence presupposes active patients with their treatment.

The concept of adherence in no way is limited to just following a pharmacologic schedule. This concept was expanded along the last decades as health concepts evolved to include social, economic, psychologic and spiritual dimensions to the concept of health and disease. Investigations and discussions on adherence have initially evolved from the one dimension approach limited to following a pharmacological schedule to the understanding of factors involved in the success or failure of a treatment or symptoms control. The approach went beyond patients. It is well known that the treatment of a disease or health condition is mediated by several factors.

The adherence model proposed by the World Health Organization $(\mathrm{WHO})^{3}$ illustrates the participation of some factors in the adherence process, namely, aspects regarding the health team, factors related to treatment itself, aspects related to the disease, patients and socioeconomic factors.

With regard to disease-related aspects, one may stress symptoms magnitude or absence, disease characteristics, its evolution, chronicity, impact on patients' lives. In this sense, NP is a common public health problem, being classified as a difficult to control pain, characterized by frequent treatment failure associated to high costs. A multicenter study with poststroke (S) patients has shown that $81.8 \%$ of patients had NP and that pain had negatively influenced the rehabilitation program, delaying recovery and, probably increasing rehabilitation costs.

And patients with higher pain scores had more severe deterioration of mental QL aspects as compared to patients with nociceptive pain who had more severe deterioration of physical aspects ${ }^{4}$. With regard to treatment, its positive or undesirable effects, access to treatment and complex therapeutic schedules are important factors to be highlighted as to consequences or results. Socioeconomic variables also interfere with adherence, and among several factors one may mention drug cost, health policies, access to health services, waiting time versus assistance time, gender, edu- 
cational level and social class.

Patient-associated factors include from lifestyle, social network, family context, age group, emotional status, cognitive aspects (e.g., beliefs and dysfunctional beliefs) to previous experience with the disease. Health team-associated aspects are team/patient relationship, communication, professionals' beliefs, among others. Faced to this number of elements it is noticeable the complexity of the adherence process.

In the clinical context of NP treatment it is easier to notice some elements, among them poor drug effect, in many cases without total symptoms remission; drug adverse effects (e.g., sleepiness, loss of libido, torpor, constipation); and high cost of some drugs. With regard to beliefs, often patients resist to the use of opioids, antidepressants and anticonvulsants due to myths or stigmata associated to them. Physician or health team communication is also an important factor, drug or procedure functioning and effects should be clearly explained and prescriptions should be legible.

In spite of the importance of adherence and although there are some theoretical discussions since the 1950 s, the subject is poorly investigated ${ }^{5}$ and even less investigated when it comes specifically to NP.

This study aimed at summarizing literature data on adherence to NP treatment.

\section{CONTENT}

This is a literature review carried out in February 2015, in databases Pubmed/Medline and Scielo, aiming at investigating publications on NP treatment adherence. Only scientific articles published in the last 10 years (2006 to 2015), in English, Spanish and Portuguese were included. Descriptors were: "adherence", "pain", "neuropathic pain and compliance" and "pain and neuropathic pain'. Titles and abstracts were read for a pre-selection of articles and then relevant articles were read in full, thus giving subsidies to the discussion of the subject.

Table 1. Articles found in the literature review

\begin{tabular}{|c|c|c|c|}
\hline Database & $\begin{array}{l}\text { Number } \\
\text { of articles }\end{array}$ & Category & Content \\
\hline Pubmed & 91 total & Drugs & 46 drugs \\
\hline \multirow{9}{*}{ Scielo } & \multirow{3}{*}{11} & & 17 Guidelines \\
\hline & & $\begin{array}{l}\text { Non-pharmacological } \\
\text { procedures }\end{array}$ & $\begin{array}{l}6 \text { non-pharmacological } \\
\text { procedures }\end{array}$ \\
\hline & & Non-adherence & $\begin{array}{l}5 \text { psychosocial factors } \\
\text { mediating adherence }\end{array}$ \\
\hline & 17 & $\begin{array}{l}\text { No relation with studied } \\
\text { content }\end{array}$ & $\begin{array}{l}\text { Clinical conditions } \\
\text { associated to pain }\end{array}$ \\
\hline & \multirow[t]{2}{*}{87 total } & \multirow[t]{2}{*}{ Drugs } & 49 drugs \\
\hline & & & 13 Guidelines \\
\hline & \multirow[t]{2}{*}{12} & $\begin{array}{l}\text { Non-pharmacological } \\
\text { procedures }\end{array}$ & $\begin{array}{l}5 \text { non-pharmacological } \\
\text { procedures }\end{array}$ \\
\hline & & Non-adherence & $\begin{array}{l}7 \text { psychosocial factors } \\
\text { mediating adherence }\end{array}$ \\
\hline & 13 & $\begin{array}{l}\text { No relation with studied } \\
\text { content }\end{array}$ & $\begin{array}{l}\text { Clinical conditions } \\
\text { associated to pain }\end{array}$ \\
\hline
\end{tabular}

\section{DISCUSSION}

Notwithstanding several definitions developed along the years, therapeutic adherence is still difficult to evaluate or measure. By the analysis of articles found in this review, it was observed that most studies ( 46 articles in Pubmed and 49 in Scielo) have examined adherence with emphasis on drugs adverse effects or efficacy, or have compared the effects of two drugs. In addition, 17 articles were found in Pubmed and 13 articles in Scielo, with focus on professionals' adherence to guidelines proposed by guidelines entities.

Among first line drugs to treat NP there are antidepressants (tricyclic and mixture of serotonin and norepinephrine reuptake inhibitors) and antiepileptic (calcium channels $\alpha 2 \delta$ inhibitors) based on pathophysiological mechanisms involving nociceptive pathways hyperexcitability or loss of descending inhibitory analgesic system ${ }^{6}$. Efficacy and tolerability problems impairing adherence are reported in most articles in all available strategies to treat NP in different clinical conditions. In patients with postherpetic neuralgia, gabapentin is indicated as effective and welltolerated treatment $t^{7,8}$, as well as pregabalin associated to carbamazepine for refractory trigeminal neuralgia9.

Adherence among patients with NP associated to low back pain, osteoarthritis and diabetic neuropathy under doluxetine was $29.9 \%$. These results might be useful to determine adherence expectations, and how it can be different for each studied condition.

Alone, capsaicin as topical NP treatment is associated to several adverse effects, such as irritation, burning sensation and erythema, resulting in low patient adherence. However the commodity of the route and the possibility of complementary treatment make topical analgesics an interesting option due to decreased potential for adverse effects. There is major interest in the composition of topical analgesics for peripheral NP aiming at improving treatment adherence. The efficacy of $2 \%$ amitriptyline and $0.75 \%$ capsaicin in cream has been recently shown to control diabetic NP with less adverse effects and better adherence ${ }^{10}$. The combination of amitriptyline and ketamine, in turn, has controversial results as to efficacy, being necessary further studies to support the use of AK in the clinical practice ${ }^{11}$

Measurement of tricyclic antidepressants in the urine is the preferred method to monitor adherence to therapy due to easy collection. In recent retrospective analysis, adherence rate to tricyclic antidepressants was $66 \%$, as from urinary dosage. While adherence was better among older and female individuals, simultaneous use of other drugs has not affected adherence rate. A confirmation method by liquid chromatography and mass spectrometry to confirm the use of tricyclic antidepressants in urine samples has been developed, however its high cost impairs applicability ${ }^{12}$ With regard to adherence to other non-pharmacological procedures, 11 articles in Pubmed and 13 in Scielo were found which, in general, have investigated response to non-pharmacological or surgical interventions ${ }^{13}$. In this article, authors discuss efficacy, costs and compliance with radiofrequency treatment in occipital neuralgia patients. Other articles regarding adherence to other non-pharmacological procedures shall not be discussed because this is not the scope of this study.

In the group of articles investigating the participation of psychosocial aspects in the adherence process, 5 articles were found in Pubmed and 7 in Scielo. Results suggest that catastrophizing and depression beliefs may contribute for the non-adherence to antiretroviral therapy and to the use of drugs to treat pain associated to human immunodeficiency virus (HIV) neuropathy ${ }^{14}$. Health professionals' education ${ }^{15}$ and adequate communication ${ }^{2}$ between professionals and patients have also been described as major factors for pain management and adherence to treatment. Butow \& Sharp ${ }^{2}$, although not specifically addressing NP adherence, make and excellent summary of behavioral, cognitive and affective factors present in the non-adherence process.

Other three studies have described the relationship between decreased pharmacological therapy efficacy to control pain as a major factor for discontinuing the drug, without however investigating in more detail psychosocial factors determining non-adherence ${ }^{16-18}$. Other studies were also found stressing the importance of considering psychosocial factors when selecting treatments, without however describing such aspects ${ }^{19}$. Among many articles found, several did not address specifically adherence to NP treatment, but would stress the importance of some psychologic aspects influencing non-adherence (e.g., depression $)^{20}$.

It is known that patients may have different availability to deal with changes underlying coping with disease and pain. It is necessary to recognize the level of patients' motivation to follow therapies indicated by multi or interdisciplinary team, stressing the influence of pain-related beliefs, both supporting and inhibiting patients' ability to adhere to treatment recommendations along time, or even to discuss them with the team. It is worth stressing that health team beliefs and communication between health team and patients also play important role in adherence.

\section{CONCLUSION}

The small number of publications on adherence to NP treatment, large concentration of studies on adherence addressing this subject only by a 
pharmacological bias and limited number of studies investigating psychosocial aspects of non-adherence indicate that it is necessary to produce further knowledge on the subject. On the other hand, in face of reviewed literature, one may infer that studies in other areas may be useful for the understanding of NP treatment adherence process.

It is believed that more refined and standardized methodologies, expanding the investigation focus to non-pharmacological treatment and consistent descriptions of pain-related beliefs (e.g., control locus and catastrophic thoughts) may improve the understanding of adherence behaviors. Associated to this, actions regarding patients and health professionals' education have also been considered as playing important role in adherence and increased efficacy of therapies. It is believed that patients should be active partners of their own care and that good communication between patients and health professional is mandatory for an effective clinical practice.

\section{REFERENCES}

1. Timmerman L, Stronks DL, Groeneweg JG, Huygen FJ. Prevalence and determinants of medication non-adherence in chronic pain patients: a systematic review. Acta Anaesthesiol Scand. 2016;60(4):416-31

2. Butow P. Sharpe L. The impact of communication on adherence in pain management. Pain. 2013;154(Suppl 1):S101-7.

3. World Health Organization. Adherence to Long Term Therapies Project. Evidence for action. 2003 4. Aprile I, Briani C, Pazzaglia C, Cecchi F, Negrini S, Padua L. Pain in stroke patients: characteristics and impact on the rehabilitation treatment. A multicenter cross-sectional study. Eur J Phys Rehabil Med. 2015;51(6):725-36

5. Kurita GP, Pimenta CA. [Compliance with the treatment of chronic pain and healt locus]. Rev Esc Enferm USP. 2004; 38(3):254-61. Portuguese.

6. Lozeron P, Kubis N. [Management of neuropathic pain0. Rev Med Interne. 2015;36(7):480-6. French.
7. Meng FY, Zhang LC, Liu Y, Pan LH, Zhu M, Li CL, et al. Efficacy and safety of gabapentin for treatment of postherpetic neuralgia: a meta-analysis of randomized controlled trials. Minerva Anestesiol. 2014;80(5):556-67.

8. Thomas BM, Farquhar-Smith P. Gabapentin enacarbil extended release for the treatment of postherpetic neuralgia in adults. Ther Clin Risk Manag. 2013;9:469-75.

9. Rustagi A, Roychoudhury A, Bhutia O, Trikha A, Srivastava MV. Lamotrigine versus pregabalin in the management of refractory trigeminal neuralgia: a randomized open label crossover trial. J Maxillofac Oral Surg. 2014;13(4):409-18.

10. Kiani J, Ahmad Nasrollahi S, Esna-Ashari F, Fallah P, Sajedi F. Amitriptyline $2 \%$ cream vs. capsaicin $0.75 \%$ cream in the treatment of painful diabetic neuropathy (Double blind, randomized clinical trial of efficacy and safety). Iran J Pharm Res. 2015;14(4):1263-8.

11. Mercadante S. Topical amitriptyline and ketamine for the treatment of neuropathic pain. Expert Rev Neurother. 2015;15(11):1249-53.

12. Lin CN, Juenke JM, Johnson-Davis KL. Method validation of a tricyclic antidepressant drug pane in urine by UPLC-MS/MS. Ann Clin Lab Sci. 2014;44(4):431-6.

13. Weinstein JN, Tosteson TD, Lurie JD, Tosteson AN, Hanscom B, Skinner JS, et al. Surgical vs nonoperative treatment for lumbar disk herniation: the Spine Patient Outcomes Research Trial (SPORT): a randomized trial. JAMA. 2006;296(20):2441-50

14. Lucey BP, Clifford DB, Creighton J, Edwards RR, McArthur JC, Haythornthwaite J. Relationship of depression and catastrophizing to pain, disability, and medication adherence in patients with HIV-associated sensory neuropathy. AIDS Care. 2011;23(8):921-8

15. Lavoie Smith EM, Bakitas MA, Homel P, Fadul C, Meyer L, Skalla K, et al. Using quality improvement methodology to improve neuropathic pain screening and assessment in patients with cancer. J Cancer Educ. 2009;24(2):135-40.

16. Wilkie DJ, Molokie R, Boyd-Seal D, Suarez ML, Kim YO, Zong S, et al. Patient-reported outcomes: descriptors of nociceptive and neuropathic pain and barriers to effective pain management in adult outpatients with sickle cell disease. J Natl Med Assoc. 2010;102(1):18-27.

17. Nantz E, Liu-Seifert H, Skljarevski V. Predictors of premature discontinuation of treatment in multiple disease states. Patient Prefer Adherence. 2009;3:31-43.

18. Sanders S, Herr KA, Fine PG, Fiala C, Tang X, Forcucci C. An examination of adherence to pain medication plans in older cancer patients in hospice care. J Pain Symptom Manage. 2013;45(1):43-55.

19. Stump PR, Dalben Gda S. Mechanisms and clinical management of pain. Braz Oral Res 2012;26(Suppl 1):115-9.

20. Reich M. Depression and cancer: recent data on clinical issues, research challenges and treatment approaches. Curr Opin Oncol. 2008;20(4):353-9. 